\title{
Strategy for Handling Covid-19 in the Perspectives of Policy Implementation, Community Institutions and Community Participation in Cileunyi Sub-District
}

\author{
Ono Taryono*, Siti Widharetno Mursalim, Saekul Anwar \\ STIA LAN Bandung Polytechnic \\ Bandung, Indonesia \\ *ono.taryono@poltek.stialanbandung.ac.id
}

\begin{abstract}
The Covid 19 pandemic is increasingly difficult to control, so the Indonesian government at all levels must fight hard to stop its spread. Therefore, integrated efforts need to be made to deal with this pandemic that include the implementation of policy for handling Covid 19 by the government, the role of social institutions, and community participation. The purpose of this research is to analyse the Covid 19 handling strategy in the perspectives of policy implementation, community institutions and community participation in Cileunyi Sub-district, Bandung District. This research employs a qualitative method, and the data were collected through literature and document reviews, interviews with relevant informants, and observations. The analysis results showed that the implementation of the Covid 19 handling policy in Cileunyi sub-district was carried out in accordance with the Decree of the Governor of West Java No. 443 / Kep.189-Hukham/2020. Meanwhile, the role of social institutions from the preparation to the implementation stage is very decisive in overcoming Covid 19. The role of social institutions in handling Covid 19 is very crucial. However, the community did not fully participate in implementing 3M (washing hands, wearing masks, and maintaining physical distance) to cut the chain of Covid 19 spread. Furthermore, their social participation in handling Covid is carried out by controlling and monitoring the movement of people in their neighbourhood residents, providing daily need assistance for sufferers, conducting fundraising activities, providing sanitizers in public facilities, spraying disinfectants, conducting selfexamination and isolation for sufferers, and self-quarantine for those who had interacted with sufferers. Based on the research finding, the local government, the community organizations and the community in Cileunyi Sub-district need to strengthen their collaboration in handling the Covid 19.
\end{abstract}

Keywords-covid-19, policy implementation, community institution, participation

\section{INTRODUCTION}

Since first identified in Wuhan, China, at the end of 2019, COVID-19 has turned into a major disaster that has shaken the entire population in the world. All segments of human life are disturbed and must have a change. Many countries have decided to apply lock-down, including Indonesia, which is still implementing PSBB (Large-Scale Social Restrictions). The crisis came suddenly, governments in any part of the world, including Indonesia, had to make a bitter decision to reduce people's contact massively, to save lives and maintain economic sustainability.

The Covid-19 disease is a global health epidemic [1], and the largest outbreak of unusual pneumonia since the severe acute respiratory syndrome or popularly known as SARS outbreak in 2003. Within weeks of the initial outbreak, the total number of cases and deaths exceeded those of SARS [2]. The first outbreak was reported around December 2019 when clusters of pneumonia cases of unknown etimology were found in a seafood market in the city of Wuhan, Hubei Province, China [3]. Since then, the number of cases has increased exponentially within and beyond Wuhan, spreading to more than 34 regions in China by 30 January 2020. On the same day, the World Health Organization (WHO) warned that the Covid19 outbreak is health emergency and consider of international threat [4].

Covid-19, similarly to SARS, is a beta-coronavirus that can be transmitted to humans through intermediate hosts such as bats [5]. However, the actual route of transmission is still uncertain. Human-to-human transmission has been observed via virus-laden respiratory droplets, as a growing number of patients reportedly did not have animal market exposure, and cases have also occurred in healthcare workers [6]. The reporting rate after January 17, 2020 has been considered to have increased 21-times in comparison to the situation in the first half of January 2020 [1]. The average incubation period is calculated to be 5.2 days, with significant variation among patients suffering it [1].

In Indonesia, Covid 19 was firstly confirmed to have spread to Indonesia on March $2^{\text {nd }}, 2020$, after a dance instructor and her mother tested positive for the virus. Both were infected by a Japanese national while having a dance on February 14, 2020 [7]. Since that time, the Indonesian government has implemented various policies to suppress the spread of Covid 
19 for example the implementation of work from home, the limitation of mall operation, the banning of mudik etc.

The Deep Knowledge Group report published in Forbes on April 13, 2020 showed that Indonesia is in the highest risk category of experiencing failure in dealing with the Covid-19 pandemic. In addition, Indonesia is also in the lower category with the level of security and the threat of Covid-19. This requires institutional synergy and coordination. This situation is multidimensional, and therefore in handling Covid 19 requires the involvement and synergy of all elements of governance [8]. Of course, this is not easy, especially for a plural and decentralized Indonesian government system. This becomes a challenge that must be managed [9]. As a result, there is no fragmented handling.

Cileunyi sub district is one of the areas infected by covid 19. The first case was confirmed around April 2020. Based on PRFM news of December 2nd, 2020. This sub-district has the highest number of cases in Bandung District. 92 sufferers and 10 suspects. Since that time, the government of Cileunyi subdistrict had implemented various efforts to deal with the case, starting from restricting community activities, socializing the prevention of the covid 19, etc. All implementation of handling Covid-19 in Cileunyi refers to the Decree of the Governor of West Java Number 443 / Kep. 176-dinkes / 2020 concerning the prevention and control of Covid-19 in West Java.

One of the strategies that the government can implement to handle this covid 19 is the Pentahelix Model. The 'Penta-Helix Model' is based on five stakeholder types: businesses, public administration, residents, the knowledge sector, and capital. The model is very useful for multi stakeholder problem areas where stakeholders represent a range of interests on a site or problem. Penta helix [10] is an extension of the triple helix strategy by involving various elements of the community or non-profit institutions to realize the innovation. Through synergistic collaboration it is expected to realize an innovation that is supported by a variety of resources that interact synergistically.

The partnership in handling covid 19 involves the activeness of every party in a nation. Without that the pandemic cannot be overcome. This study tries to demonstrate strategy for handling covid-19 in the perspectives of policy implementation, community institutions and community participation in Cileunyi sub-district.

\section{RESEARCH MethodS}

This research employed a descriptive qualitative method. It aims to figure out a strategy for handling covid-19 in the perspectives of policy implementation, community institutions and community participation at Cileunyi sub-district. Qualitative research is research based on the philosophy of post positivism used to examine the condition of natural objects where the researcher as a key instrument and the results of his research emphasizes the meaning of generalization [11]. Descriptive research is research done to describe a variable, either one variable or more (independent) without making comparisons, or linking one variable with another variable [11]. It represents an inquiry process of understanding based on distinct methodological traditions of inquiry that explore a social or human problem. Then, the researchers build a complex, holistic picture, analyse words, report detailed views of informants, and conduct the study in a natural setting. This study was conducted from August-December 2020. By using purposive sampling technique, the researchers interviewed some informants assumed to have sufficient information concerning the pandemic condition and the countermeasure efforts against it at Cileunyi sub-district. The informants comprised the Head of Cileunyi sub-district, the heads of village within Cileunyi sub-district, Head of Social section, Head of Government Section the leaders of PKK (Family Welfare Program) at village level, the leaders of LPMD (Village Community Empowerment Institution), the leaders of PMD (Village Empowerment Body), and the village coordinators of Covid-19 countermeasure. To support the primary data from the interviews, the researchers also reviewed some relevant documents, such as the sub-district profile, quarterly reports, and village profiles, as well as supporting information from various virtual resources. The sampling was obtained through purposive sampling. The informants of this study consist of the element of Sub District government (4 informants) and village government (10 informants from the head of the village and the coordinator of the Covid 19 Taskforce).

\section{RESULTS AND DISCUSSION}

\section{A. Covid Handling Policy in Cileunyi Sub District}

Implementation is considered as the main form and a very decisive stage in the policy process $[12,13]$. This view is supported by the statement of Edwards III [14] that without effective implementation the decision of policy makers will not be successful. Policy implementation is an activity that is seen after a valid direction has been issued from a policy which includes efforts to manage inputs to produce outputs or outcomes for the community.

According to Grindle [15], the policy Implementation is not only concerned with the mechanism of translating political decisions into routine procedures through bureaucratic channels, but more than that, it concerns conflicts, decisions and who gets what from a policy. Therefore, policy implementation is an integral and important aspect of the entire policy process. Moreover, Grindle asserted that the success of a public policy implementation is largely determined by the level of implementation of the policy itself, which consists of Content and Context of Policy.

The Covid-19 Handling Policy in Cileunyi Sub District refers to policies issued by the central government, governors, and regents and Decree of the Governor of West Java Number 443 / Kep.176-dinkes / 2020 concerning the Prevention and Control of Coronavirus Disease-19 (Covid-19) in West Java. The government of Cileunyi sub-district did not issue anyregulation yet to strengthen such regulation because they think 
that the regulation is quite clear for them. They just issued a decree concerning the COVID-19 task force coordinated by $a$ Camat (head of the sub-district) to ease them in delivering any assistance from the government.

At Rural level, the Villages form a task force to accelerate the handling of covid-19. The villages provide appeals and outreach to residents to avoid crowds and always adhere to health protocols. The village government in Cileunyi subdistrict refers to the PDTT Permendesa 14 of 2020 concerning the Third Amendment to the 11 Year 2019 PDTT Permendesa concerning Priority for the Use of Village Funds in 2020 in handling Covid-19. The village government in Cileunyi subdistrict also did not issue any regulation concerning covid handling and the only regulation issued was just a decree related to Covid 19 Handling taskforce. They just referred to the regulation that has been issued by the government especially in allocating village funds.

The use of Village Funds is guided by the priorities for the use of Village Funds stipulated by the Minister of Village, Development Disadvantaged Areas and Transmigration. The priority for the use of Village Funds in the context of handling the COVID-19 pandemic includes activities to procure basic needs for affected Village residents, procurement of equipment materials, health, and other activities in accordance with applicable regulations. The village government is also obliged to establish a social safety net in the village in the form of Village Direct Cash Assistance (BLT) for poor or underprivileged families in the village. Based on the reallocation of the use of the Village Fund, the Village Head establishes village regulations regarding changes to the Village Budget.

Although there is no regulation issued both by the sub district and village government of Cileunyi related to Covid handling in their area, they always convey recommendation to society through WhatsApp groups, banners and any other media to make the village community aware of the danger of Covid 19. They always remind the community to apply the strict health protocol wherever they are, stay away from the crowd and keep the environment hygiene and clean.

\section{B. The Role of Community Institution}

Institutions have an important role in dealing with Covid19. Institutions are rules in community groups with the purpose of achieving the desired goals [16].

Community institutions in handling Covid-19 in Cileunyi District are managed by the village government led by the Village Head and assisted by youth organizations, PKK, LPMD, religious institutions and RT / RW in accordance with the Task Force Decree in each village.

In the process, the role of community institutions in handling Covid-19 was seen from 7 aspects. Starting from the preparation, the assessment, the alternative planning, the action plan formulation, the implementation, the evaluation, and the termination stage.
In the implementation stage, the role of community institutions is coordinated by each village in Cileunyi District. Of the 6 villages in Cileunyi District, the role of community institutions in helping to handle Covid-19 is very good, this can be seen from 7 aspects of community institutions.

The preparation stage was carried out when the Covid case began to expand in Indonesia, to be precise in February. The head of the Cileunyi sub-district and his staff immediately held a meeting with all village heads in the Cileunyi sub-district. From this meeting, Camat (the head of subdistrict) of Cileunyi instructed the village head to form a task force at the village level. The task force that was formed consisted of LPMD, PKK, youth organizations, religious institutions, community leaders and RT / RW.

Furthermore, at the assessment stage, the process of identifying problems that arise was conducted by a hearing with community representatives in the village which results in various kinds of identification of problems. This activity was done periodically by the Covid 19 task force in Subdistrict and Village Level.

At the alternative planning stage, community organizations played an active role in planning. Many of the ideas for handling Covid-19 come from the community. Therefore, there is good cooperation among community institutions in Cileunyi District.

After the planning process for handling Covid-19 was carried out, the next stage was the formulation of an action plan. At this stage, many creative and innovative programs have sprung up from the community, including the establishment of rice ATMs intended for those who have an impact on Covid, a 24-hour call centre to serve emergency, cars, village gardens to protect the psychology of residents so they don't experience stress during Covid. Furthermore, they also create a community radio that reports the latest update about the Covid-19 case in Cileunyi District, besides making public kitchens and isolation rooms specifically for communities affected by Covid-19.

After the program was created, it was run cooperatively by community organizations and residents in Cileunyi subDistrict. For example, the implementation of public kitchens is coordinated by the PKK, community radio by Karang Taruna, ATMs by LPMD and residents. Likewise, many of the funds for handling Covid came from the community. Therefore, it seems that all parties play a very big role in helping to handle and prevent Covid-19 in Cileunyi District.

Moreover, there is always an evaluation of the programs that have been carried out through routine weekly meetings to anticipate various possibilities that will arise and solve the problems in handling Covid-19 in Cileunyi ub district area.

\section{Community Participation in Handling Covid- 19}

The community participation in handling pandemic conditions comprises the social participation [17] and the participation in policy implementation [18]. In terms of social 
participation, the community have participated in forms of: 1) controlling and monitoring the movement of people in their neighbourhood residents; 2) providing daily need assistance for sufferers; 3) conducting fundraising activities; 4) providing sanitizers in public facilities such as mosques and village government offices; 5) assisting the village government to spray disinfectants; and 6) conducting self-examination and isolation for sufferers, and self-quarantine for those who had interacted with sufferers.

The Covid-19 sufferers and suspects are usually commuters who live in the village but work outside the district. They work in Bandung City, Cimahi City, and other regions. Thus, when they caught the Covid-19, they brought the disease into the village. The sufferers could also be guests or relatives from other regions who came into the village and got sick. No local community members had been affected by the disease so far. The sufferers then voluntarily conducted self-quarantine for fourteen days in their houses or in a tent provided the village government for the sufferers. Their daily activities were actively monitored by the village coordinator of Covid-19 countermeasure and members of the committee, and their health progress was monitored to ensure they really recovered from the illness and would not spread the disease to others. Thus, those who came into the village, or wanted to leave the village for their hometowns had to fill in a form, and they had to properly have their health conditions checked. This is to make sure that they were not affected by the virus and would not spread the virus to others.

The village communities voluntarily helped the sufferers by providing groceries to fulfil their daily needs such as rice, eggs, coffee, sugar, tea, and others. The groceries were supplied by the community members and village religious institutions (DKM/mosque prosperity boards). The groceries were handed to the head of hamlet, which were then distributed to those in need. The members of PKK (Family Welfare Program) also opened a public kitchen and cooked some food for the Covid19 suspects and sufferers.

In addition to the village religious institutions (DKM / mosque prosperity boards), such other community organizations as the village youth organization (karang Taruna) raised some funds from the local communities within hamlets. The assistance in the forms of cash and food supply were collected and submitted to the village authority. The collected amount of assistance was much higher than the financial stimulant provided by the village government. This indicates that the community within Cileunyi sub-district had a sense of solidarity with the suspects and those affected by Covid-19.

Public places like the mosques/mushallas and the village government offices took part in curbing the spread of Covid-19 by supplying hand sanitizers, hand soap, water, and handwashing basin for those who wanted to pray or visited the village government office. However, there was no sign of monitoring from the authority to push people from utilizing the facilities. Some people used the facilities, some did not. When performing observations in some village government office and in the sub-district office, no officers were assigned to watch and direct people to the hand-washing basin to clean their hands by using the hand soap and water.

It is the duty of the village government through the Village Coordinator of Covid-19 Countermeasure to make various efforts to reduce the spread of Covid-19, including spraying disinfectants to all corners of the area, especially residential areas. Even so, the community was enthusiastic to participate in the disinfectant spraying activity. The community at the RW level was also enthusiastic about spraying in their own environment. If the community did not have the spray equipment, they could borrow it from the village government.

The community also participated in conducting selfexamination and isolation for sufferers, and self-quarantine for those who have interacted with sufferers. At the RW level, the community formed their own Covid-19 task force, and they had a post. If there were positive for Covid, then the RW-level Covid task force would monitor their movements. This was conducted so that the Covid-19 would not spread to other residents. The RW task force also collected the data of people coming into the village by filling out a form, and they had to undergo an independent quarantine for 14 days. After that the $\mathrm{RW}$ task force escorted them to the nearby community health centre (Puskesmas) to carry out a health check and to make sure they did not catch Covid. At the village level, the Cibiru Wetan village government provided a large tent as a place of isolation for Covid sufferers. The tent was built on April 13, 2020. This tent was guarded by Covid task force consisting of village government officials, LKMD, babinsa, linmaspol, village assistants, and RT / RW. Around the tent, a public kitchen was built to provide food for sufferers who conducted self-isolation. People who had finished their isolation were welcomed by the community as if they had returned from Umrah / pilgrimage to Mecca to their home.

Apart from the various community participations that have been mentioned above, there is quite encouraging news made by the Cibiru Wetan village government apparatus, namely participation in food security during pandemic. During the 8 months of the leadership of the current village head, next to the village government office have been established a learning park, children's playground, and a hydroponic garden. The purpose of creating this hydroponic garden is to provide lessons for villagers to remain productive and be able to use land to produce staple goods for the community, especially during pandemic. In one hamlet (RW), the PKK members have been developing this hydroponic system, and until now they have saved Rp. 100 million from selling hydroponic vegetable crops.

The community participation in policy implementation against the spread of Covid-19 took place in the forms of: 1) physical distancing to avoid wider spread of Covid-19, 2) social distancing - a step in preventing and controlling the Corona virus infection by prohibiting people to have on-site visits to crowded places and to have direct contact with other people, 3) mask wearing, and 4) handwashing. In terms of 
physical distancing, according to the explanation of the village government apparatus, the community no longer needs to be called on to carry out physical distancing. The community is thought to understand that they must keep their distance in this pandemic era. In carrying out their religious obligations, such as in a prayer room, the distance of the shaf is regulated according to the protocol, which is about 1 meter. Those who want to pray are also advised to bring their own prayer mats so that they are safe from exhalation and splashes of liquid that come out of other people, who may have Covid-19. Before entering a place of worship, worshipers are required to wash their hands with soap. Meanwhile, other community activities such as feasts conducted by community members, can take place, but protocols must be performed, and the number of people invited must be reduced. Those who have a desire to conduct feasts must provide masks and a place to wash hands along with hand washing soap. If they violate this provision, then the feasts such as circumcisions and wedding parties will be dismissed by the police. During the month of Ramadhan, Cibiru Wetan village had Ramadan culinary activities. Village government officials did not stop the activities because they were worried about the impact on the community's economy. However, its implementation is regulated in such a way that it meets the health protocol. Each stand is given an odd / even number, and the stands that may open are adjusted to the date. If the date is even, the only booths allowed to open are those with even numbers. Likewise, if the date is odd, only stands with odd numbers may be open.

For social distancing, the village government in Cileunyi sub-district does not prohibit social activities, such as performing congregational prayers at mosques / prayer rooms, family celebrations, and village markets. However, its implementation must follow the health protocol. Shaf in prayer is given a distance of 1 meter. The community organizing the feasts may only invite a limited number of guests. That is according to the provisions conveyed by the village government. In practice, when the researchers were there, the researchers witnessed a cultural parade activity being held on the village main road. The village main road was very crowded, there were so many people, and they rarely wore masks and did not keep their distance from each other. Furthermore, what is difficult to control is the traditional market conditions, where people come there to buy daily necessities or make economic transactions. This condition was almost the same for all areas of Bandung Regency. People flocked without heeding health protocols.

Meanwhile, for mask wearing when leaving the house, based on the results of field observations, some people obeyed wearing masks when leaving the house but some of them did not comply with health protocols. They were in public places, such as in the food stalls (warung) or shops in the village without wearing masks, and without maintaining a distance. Perhaps they thought that none of their neighbours had Covid19. They were so busy mingling and chatting as if there had been no Covid-19 pandemic.
Handwashing seems to be a trivial thing to do. However, it may be a hard thing when people must do it frequently. Although the washbasin, water and soap were provided in such public places as worship places, the sub-district government office, and the village government office, not all people visiting those places were willing to do it amidst this pandemic era. They might have been bored of doing it many times during the day.

The community's boredom, negligence, and ignorance toward the health protocols after months of pandemic represent an alarming sign for the Indonesian government. It proved that the prevalence of Covid-19 sufferers in Indonesia including Cileunyi Sub-district kept rising, and Cileunyi sub-district was categorized as a 'red zone'. Based on PRFM news of December $2^{\text {nd, }} 2020$, this sub-district had the highest number of cases in Bandung District, 92 sufferers and 10 suspects.

\section{CONCLUSION}

From the research results, the aspects of Policy implementation, social institutions and community participation in handling Covid-19 have yet to improve. There should be a mechanism to make the community comply with the health protocols. Since it is unlikely for the local government to monitor the community compliance to the health protocols up to the village community level, the roles of village and hamlet Covid-19 task forces can be strengthened to function as the watchdog for the local government to monitor and enforce the necessary efforts to curb the development of Covid-19 within their territory. Furthermore, in implementing policies, policies that regulate the sub-district and village levels are needed to be able to regulate more technical matters and prevent the spread of Covid-19. Therefore, the strategy to be followed up includes: 1) increasing synergy between the government, social institutions and the community, 2) strengthening policies at the local level: sub-districts and villages, and 3) conducting more research after the pandemic crisis over.

\section{REFERENCES}

[1] S. Zhao, S.S. Musa, Q. Lin, J. Ran, G. Yang, W. Wang, Y. Lou, L. Yang, D. Gao, D. He and M.H. Wang, "Estimating the unreported number of novel coronavirus $(2019-\mathrm{nCoV})$ cases in China in the first half of January 2020: A data-driven modelling analysis of the early outbreak," Journal of Clinical Medicine, vol. 9, no. 2, pp. 388, 2020.

[2] L. Hawryluck, W.L. Gold, S. Robinson, S. Pogorski, S. Galea and R. Styra, "SARS control and psychological effects of quarantine, Toronto, Canada," Emerging infectious diseases, vol. 10, no. 7, pp. 1206, 2004.

[3] H. Nishiura, T. Kobayashi, T. Miyama, A. Suzuki, S.M. Jung, K Hayashi and N.M. Linton, "Estimation of the asymptomatic ratio of novel coronavirus infections (COVID-19)," International journal of infectious diseases, vol. 94, pp. 154, 2020.

[4] E. Mahase, "Covid-19: WHO declares pandemic because of "alarming levels" of spread, severity, and inaction," Bmj, vol. 368, 2020.

[5] C.I. Paules, H.D. Marston and A.S. Fauci, "Coronavirus infectionsMore than just the common cold," JAMA, vol. 323, no. 8, pp. 707, 2020.

[6] Y. Li, Z. Wang, Y. Hui, X. Tong, X. Mao, L. Huang and D. Zhang, "Clinical characteristics of 77 novel coronavirus 2019 infected patients 
with respiratory failure in the terminal stage in Wuhan," SSRN Electronic Journal, 2020.

[7] The Jakarta Post, Breaking: Jokowi announces Indonesia's first two confirmed COVID-19 cases [Online]. Retrieved from: https://www.thejakartapost.com/news/2020/03/02/breaking-jokowiannounces-indonesias-first-two-confirmed-covid-19-cases.html, 2020.

[8] T. Christensen, P. Lægreid and L.H. Rykkja, "Organizing for crisis management: Building governance capacity and legitimacy," Public Administration Review, vol. 76, no. 6, pp. 887-897, 2016.

[9] W. Mas'udi and A. Astrina, Problematika Kebijakan Krisis Covid-19 di Indonesia. Policy Brief. Edisi 1. Yogyakarta: FISIPOL UGM, 2020.

[10] E. Sturesson, A. Lindmark and R.M. Nilsson, Collaboration for Innovation-a study in the Öresund Region, 2009.

[11] S. Sugiyono, Metode penelitian pendidikan: (pendekatan kuantitatif, kualitatif Dan R \& D), 2009.

[12] T.A. Birkland, An introduction to the policy process: Theories, concepts, and models of public policy making. Routledge, 2019.
[13] R. Heineman, The World of Policy Analyst. NY: Chatham House Publishers, Inc, 1997.

[14] P.R. Gangadharam and C.K. Edwards III, "Release of superoxide anion from resident and activated mouse peritoneal macrophages infected with Mycobacterium intracellulare," American Review of Respiratory Disease, vol. 130, no. 5, pp. 834-838, 1984.

[15] M.S. Grindle, Politics and Policy Implementation in The Third World. New Jersey: Princnton University Press, 1980.

[16] V.W. Ruttan and Y. Hayami, "Toward a theory of induced institutional innovation," The Journal of development studies, vol. 20, no. 4, pp. 203223, 1984.

[17] A. Huraerah, Pengorganisasian dan Pengembangan Masyarakat-Model dan Strategi Pembangunan Berbasis Kerakyatan. Bandung: Humaniora, 2008.

[18] J.M. Cohen and N. Uphoff, Rural development participation: Concepts and measures for project design. Implementation and Evaluation: Cornell University, Ithaca, 1977. 